Magazine of Concrete Research Volume 67 Issue 12

Effect of fine ceramic recycled aggregate (RA) and mixed fine RA on hardened properties of concrete

Etxeberria and Vegas
Magazine of Concrete Research, 2015, 67(12), 645-655

\title{
Effect of fine ceramic recycled aggregate (RA) and mixed fine RA on hardened properties of concrete
}

Miren Etxeberria

Associate Professor, Department of Construction Engineering, Polytechnic University of Catalonia, Barcelona, Spain
Iñigo Vegas

Senior Researcher, Sustainable Construction Division, Tecnalia, Derio, Spain

The ceramic industry is well known for producing large amounts of rejected ceramic waste. During the construction and demolition waste crushing process, a large amount of fine recycled aggregates (FRA) are usually produced. However, little research work has been carried out employing those types of aggregates in recycled aggregate concrete (RAC) production. In this research work, mixed and ceramic FRA in partial replacement of 10, 20, 35 and 50\% of natural fine aggregates were used in order to verify their applicability in RAC manufacturing. All the concretes were produced to have the same workability. The physical, mechanical and durability properties of the RAC were determined and compared with the results obtained for conventional concrete. The results showed that an increase in the percentages of FRA used in the concrete production led to a decrease in density and an increase in water absorption. The mechanical and durability properties of all the concretes produced with fine ceramic recycled aggregates were similar to those of conventional concrete at 28 days. However, after 1 year, the compressive strength and chloride diffusion of the RAC mixtures produced using fine ceramic recycled aggregates were considerably higher than those of conventional concrete.

\section{Introduction}

Over the past century there has been a tremendous degradation of natural areas due to the large expansion of the construction industry and its use of natural resources. The concrete industry in particular is one of the major global consumers of natural resources. In order to minimise this impact, experts consider the manufacture of concrete a possible destination for waste and also a source for new aggregates to be used in new concrete life cycles.

Spain produced around $40 \mathrm{Mt}$ of construction and demolition waste (CDW) per year during the Spanish building boom, with a corresponding decrease during the period between 2008 and 2013 (Jimenez et al., 2010). Approximately 75\% of CDW is composed of mixed ceramic fractions such as bricks, tiles and concrete (European Commission, 1999; MMAMRM, 2009). It has been reported that the majority of these wastes are directly landfilled, with only $40 \%$ appropriately treated in recycling plants (Jimenez et al., 2010). In order to foster the use of larger amounts of recycled aggregates (RAs) in concrete, knowledge of the effect of RAs in cement-based materials is necessary.

Aggregates account for some $70-80 \%$ of the total volume of concrete and consequently any reduction in the consumption of natural aggregates would have a significant beneficial impact on the environment. For this reason, the use of recycled CDW as concrete aggregate has been studied in recent years. Recycled concrete aggregates have been extensively studied for concrete production for more than 50 years (Etxeberria et al., 2007; Hansen, 1986, 1992; Limbachiya et al., 2000; Poon et al., 2004; Sague-Crentsil et al., 2001; Silva et al., 2014), but studies on the utilisation of ceramic or mixed coarse RAs are relatively new. According to de Brito et al. (2005), Correia et al. (2006) and Gomes and de Brito (2009), concretes produced with recycled ceramic coarse aggregates achieve suitable mechanical properties, although the reduction in compressive strength is larger than that of flexural strength. The abrasion resistance of such concretes is higher than that of concrete made with limestone aggregate. From a durability point of view, concretes made with partial substitution of natural aggregates for ceramic aggregates obtained adequate properties.

According to Medina et al. (2012, 2013), RA concretes produced with ceramic aggregates exhibit superior mechanical behaviour compared with conventional concrete. It was also reported that the microstructure in the interfacial transition zone (ITZ) between the recycled ceramic aggregate and the paste was more compact than in the case of natural aggregate and paste. However, concretes containing recycled ceramic aggregate reveal greater sorptivity than conventional concretes. According to Senthamarai 
and Devadas Manoharan (2005) and Senthamarai et al. (2011), ceramic electrical insulator waste coarse aggregate can be used for the production of concrete that complies with the requirements of permeation characteristics set by the relevant standards.

It is also known that between $30 \%$ and $50 \%$ of the RA produced in the recycling process is fine aggregate (Vegas et al., 2011). However, due to its high absorption, low density and the potential presence of impurities, little research has been carried out with respect to its use in concrete manufacturing. The suitability of fine ceramic RAs for use in different low- or moderate-grade applications (lower compressive strength than that defining highperformance concrete (HPC), $62 \mathrm{MPa}$ according to ACI), has been verified by several authors (Alves et al., 2014; Binici, 2007; Halickaa et al., 2013; Khatib, 2005; Pacheco-Torgal and Jalali, 2010; Torkittikul and Chaipanich, 2010).

Correia et al. (2006) and Silva et al. (2014) concluded that RA concrete could achieve the properties of conventional concrete for a replacement of natural aggregates with fine ceramic aggregates up to $50 \%$. Torkittikul and Chaipanich (2010) also established $50 \%$ of fine ceramic aggregates as the optimum replacement ratio in order to maintain similar workability and compressive strength to those of conventional concrete. However, Khatib (2005) reported that even at $100 \%$ of fine aggregate replacement the reduction in strength was only $10 \%$ and indicated that this could be due to a cementing action in the presence of fine ceramic aggregates. Furthermore, Khatib (2005) and Pacheco-Torgal and Jalali (2010) showed that the increase in compressive strength over time for all mixes containing crushed bricks was higher than for mixes just containing crushed concrete and natural aggregates. All samples showed a high resistance to chloride penetration and durability, confirming the positive impact of using these aggregates. Higashiyama et al. (2012a, 2012b) also came to the same conclusions with respect to durability.

Some authors (Suzuki et al., 2009; Vejmelková et al., 2012) have suggested that the use of recycled ceramic materials could enhance HPC, offering an additional value to ceramic waste. Suzuki et al. (2009) used porous coarse ceramic waste aggregates for the internal curing of HPC. Their research found a high effectiveness of ceramic aggregates in the reduction or even complete elimination of autogenous shrinkage. The incorporation of $40 \%$ coarse mixed aggregate led to a non-shrinking HPC accompanied by a significant increase in compressive strength. For HPC incorporating waste sanitary ceramic aggregate, Halickaa et al. (2013) found the concrete elements to have the properties necessary for high-temperature applications.

There is a need to extend current knowledge regarding the use of fine RAs. In the work reported here, mixed fine RAs obtained from a CDW treatment plant and fine ceramic RA obtained from crushed rejected bricks were used as partial replacements $(10 \%$, $20 \%, 35 \%$ and $50 \%$ ) of natural fine aggregates in order to verify their applicability in concrete manufacture. The physical, mech- anical and durability properties of the RA concretes were determined and the results were compared with those of conventional concrete.

\section{Experimental details}

\section{Materials}

\section{Cement}

Type I Portland cement (CEM I 52.5 R) was used in all the concrete mixtures. The high strength and rapid hardening cement presented a specific surface of $4600 \mathrm{~cm}^{2} / \mathrm{g}$. Its chemical composition is given in Table 1.

\section{Natural quarry aggregates}

The raw crushed aggregates used in the experimental phase were fine aggregate (FA 0-4 mm), coarse aggregate type 1 4-12 mm (CA1) and coarse aggregate type 2 12-20 mm (CA2) from a limestone quarry. Densities and absorption were determined according to UNE EN 1097-6:2001 and are presented in Table 2. The particle size distribution of the natural aggregates (see Figure 1) was determined according to UNE EN 933-2:1996 (BSI, 1996). All fractions of natural aggregates satisfied the requirements specified by the Spanish standard for structural concrete (EHE, 2008).

\section{Recycled aggregates}

The following two types of fine RAs were used as partial substitutions for natural sand.

- Ceramic recycled sand. Rejected bricks were collected from the Piera Ecocerámica company and were crushed in the

$\begin{array}{lr}\text { Silicon dioxide }\left(\mathrm{SiO}_{2}\right): \% & 20 \cdot 0 \\ \text { Iron oxide }\left(\mathrm{Fe}_{2} \mathrm{O}_{3}\right): \% & 3 \cdot 4 \\ \text { Aluminium oxide }\left(\mathrm{Al}_{2} \mathrm{O}_{3}\right): \% & 5 \cdot 3 \\ \text { Calcium oxide }(\mathrm{CaO}): \% & 62 \cdot 5 \\ \text { Magnesium oxide }(\mathrm{MgO}): \% & 2 \cdot 0 \\ \text { Potassium oxide }\left(\mathrm{K}_{2} \mathrm{O}\right): \% & 0 \cdot 9 \\ \text { Sodium oxide }\left(\mathrm{Na}_{2} \mathrm{O}\right): \% & 0 \cdot 1 \\ \text { Sulfur trioxide }\left(\mathrm{SO}_{3}\right): \% & 3 \cdot 2 \\ \text { Loss on ignition: \% } & 2 \cdot 5\end{array}$

Table 1. Chemical composition of the cement used

\begin{tabular}{lccc}
\hline & $\begin{array}{c}\text { CA2 } \\
12-20 \mathrm{~mm}\end{array}$ & $\begin{array}{c}\text { CA1 } \\
4-12 \mathrm{~mm}\end{array}$ & $\begin{array}{c}\text { FA } \\
0-4 \mathrm{~mm}\end{array}$ \\
\hline Dry density: kg/dm & 2.65 & 2.64 & 2.58 \\
Water absorption: \% & 0.67 & 0.87 & 1.68
\end{tabular}

Table 2. Properties of natural aggregates 


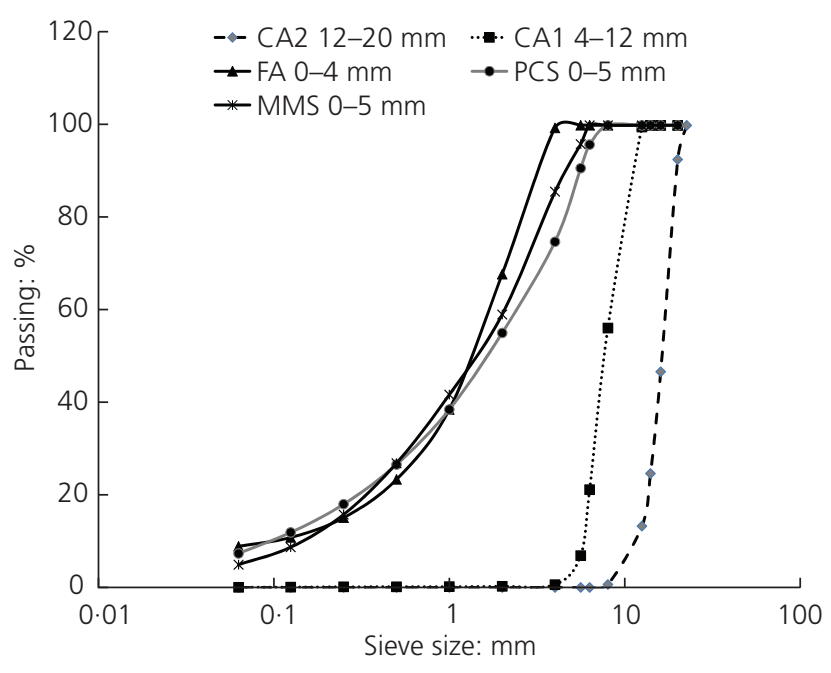

Figure 1. Particle-size distribution of natural and RAs

university's laboratory using an impact crusher; this aggregate was called PCS (Piera ceramic sand) and was composed of $100 \%$ ceramic material.

- Fine mixed RA. This was produced in a recycling plant in Montoliu (Barcelona) managed by Gestora de runes de la construcció S.A. It was produced by crushing mixed CDW and its composition was approximately $70 \%$ ceramic, $20 \%$ concrete, $9 \cdot 4 \%$ natural aggregate, $0 \cdot 5 \%$ gypsum and $0 \cdot 1 \%$ other. This aggregate was called MMS (Montoliu mixed sand).

The physical properties of these fine RAs are listed in Table 3.

The particle-size distributions of the PCS and MMS aggregates were coarser than those of the natural fine aggregates (see Figure 1) and slightly coarser than the requirements of the Spanish standard for structural concrete (EHE, 2008) for use in concrete production. However, given that the fine RAs were used as partial replacements $(10 \%, 20 \%, 35 \%$ and $50 \%)$ of natural sand, the particle-size distribution of the final aggregate complied with the EHE standard.

\begin{tabular}{lrc}
\hline & PCS & MMS \\
\hline Apparent density: g/cm & & \\
Dry density: g/cm & $2 \cdot 78$ & $2 \cdot 78$ \\
Saturated surface-dry (SSD) density: $\mathrm{g} / \mathrm{cm}^{3}$ & $1 \cdot 98$ & 1.94 \\
WA $_{24}: \%$ & $14 \cdot 72$ & 2.24 \\
\hline
\end{tabular}

$\mathrm{WA}_{24}$, water absorption in $24 \mathrm{~h}$

Table 3. Physical properties of the fine RAs

\begin{abstract}
Admixture
The chemical admixture used in the manufacture of the concrete was polycarboxylate-based, especially designed for applications in concrete and prepared to improve workability even for low cement contents.
\end{abstract}

\section{Concrete mixtures}

Nine different types of concrete were produced, namely a conventional concrete (CC) and eight RA concretes. Partial substitution of $10 \%, 20 \%, 35 \%$ and $50 \%$ of the conventional sand (FA 0 $4 \mathrm{~mm}$ ) by the two types of fine RAs (PCS and MMS) was carried out. According to the different percentages of the fine RAs used, the concrete mixes containing PCS aggregate were called CP10, CP20, CP35 and CP50 and the concretes with MMS aggregates were denoted CM10, CM20, CM35 and CM50 (Table 4).

Concrete mix proportions were defined according to their maximum volumetric compaction. This mix proportion for conventional concrete was defined as 50\% fine aggregate and 50\% coarse aggregate. The distribution of coarse aggregate was $30 \%$ CA1 $(4-12 \mathrm{~mm})$ and $70 \%$ CA2 $(12-20 \mathrm{~mm})$. Some $375 \mathrm{~kg}$ of cement and an effective water/cement (w/c) ratio of 0.40 were used in order to produce $1 \mathrm{~m}^{3}$ of all defined concrete mixes. The concrete mix proportions used are defined in Table 4. The effective $\mathrm{w} / \mathrm{c}$ ratio of conventional concrete was determined and maintained constant for all concrete mixes (the effective water was the water reacting with the cement). Aggregates were used in a dry condition in order to control the effective w/c ratio in all the other concretes. The natural coarse aggregates absorbed $20 \%$ of their total water capacity (which was the water absorption capacity of aggregates submerged for up to $20 \mathrm{~min}$ ), the fine natural aggregates absorbed $50 \%$ of their absorption capacity and the fine RAs $80 \%$ of their absorption capacity. The total water amount of the concrete was considered as the amount of effective water weight plus the absorbed water for the aggregates (see Table 5). The amount of admixture used varied from $0.8 \%$ to $1.0 \%$ with respect to cement weight and the slump of all concretes were liquid $(14-20 \mathrm{~mm})$ determined by UNE EN 12350-2:2006 (Aenor, 2006). More water and a higher quantity of admixture were added to the mixer for concrete production due to the higher absorption capacity of the mixed RAs. However, due to this larger amount of added water, the initial slump of concrete produced with high percentages of mixed RAs was considerable. Tavakoli and Soroushian (1996) found that no detrimental effect in slump value occurred in concrete containing $50 \%$ of ceramic waste aggregate where the slump values were similar to the conventional control.

\section{Specimen casting and curing}

For each concrete mixture, $100 \mathrm{~mm}$ cubes were prepared to determine the hardened concrete density, absorption, accessible air voids and capillary absorption capacity. Cylinders $(100 \varnothing / 200 \mathrm{~mm})$ were used to evaluate compressive and splitting tensile strengths, elastic modulus and resistance to chloride ion penetration of concrete. 


\begin{tabular}{|c|c|c|c|c|c|c|c|c|c|}
\hline & \multicolumn{6}{|c|}{ Material: $\mathrm{kg} / \mathrm{m}^{3}$ of concrete } & \multirow[t]{2}{*}{ Admixture: \% } & \multirow{2}{*}{$\begin{array}{c}\text { Effective w/c } \\
\text { ratio }\end{array}$} & \multirow{2}{*}{ Slump: cm } \\
\hline & CEM & $\begin{array}{c}\mathrm{FA} \\
0-4 \mathrm{~mm}\end{array}$ & $\begin{array}{c}\text { PCS/MMS } \\
0-4 \mathrm{~mm}\end{array}$ & $\begin{array}{c}\text { CA1 } \\
4-12 \mathrm{~mm}\end{array}$ & $\begin{array}{c}\text { CA2 } \\
12-20 \mathrm{~mm}\end{array}$ & $\begin{array}{l}\text { Total } \\
\text { water }\end{array}$ & & & \\
\hline $\mathrm{CC}$ & 375 & 955 & 0 & 287 & 669 & $161 \cdot 5$ & $0 \cdot 8$ & 0.40 & 14 \\
\hline CP10 & 375 & 860 & 71 & 287 & 669 & $168 \cdot 9$ & 0.8 & 0.40 & 15 \\
\hline CP2O & 375 & 764 & 143 & 287 & 669 & $176 \cdot 4$ & 0.7 & 0.40 & 14 \\
\hline CP35 & 375 & 621 & 250 & 287 & 669 & $187 \cdot 5$ & 0.8 & 0.40 & 20 \\
\hline CP50 & 375 & 478 & 357 & 287 & 669 & $198 \cdot 6$ & 0.8 & 0.40 & 18 \\
\hline CM10 & 375 & 860 & 70 & 287 & 669 & $169 \cdot 4$ & $1 \cdot 0$ & 0.40 & 15 \\
\hline CM20 & 375 & 764 & 140 & 287 & 669 & $177 \cdot 3$ & $1 \cdot 0$ & 0.40 & 20 \\
\hline CM35 & 375 & 621 & 245 & 287 & 669 & $189 \cdot 1$ & $1 \cdot 0$ & 0.40 & 21 \\
\hline CM50 & 375 & 478 & 350 & 287 & 669 & $200 \cdot 9$ & $1 \cdot 0$ & 0.40 & 21 \\
\hline
\end{tabular}

Table 4. Mix proportions of concretes

\begin{tabular}{|c|c|c|c|c|c|c|c|c|c|}
\hline & $\mathrm{CC}$ & CP10 & CP20 & CP35 & CP50 & CM10 & CM20 & CM35 & CM50 \\
\hline SSD density: $\mathrm{g} / \mathrm{cm}^{3}$ & $2 \cdot 46$ & $2 \cdot 45$ & $2 \cdot 42$ & $2 \cdot 38$ & $2 \cdot 37$ & $2 \cdot 41$ & $2 \cdot 42$ & $2 \cdot 37$ & $2 \cdot 37$ \\
\hline Dry density: $\mathrm{g} / \mathrm{cm}^{3}$ & $2 \cdot 43$ & $2 \cdot 41$ & $2 \cdot 38$ & $2 \cdot 33$ & $2 \cdot 33$ & $2 \cdot 37$ & $2 \cdot 38$ & $2 \cdot 32$ & $2 \cdot 32$ \\
\hline Water absorption: \% & $1 \cdot 48$ & $1 \cdot 54$ & $1 \cdot 78$ & 1.97 & $1 \cdot 88$ & $1 \cdot 53$ & $1 \cdot 65$ & $2 \cdot 03$ & $2 \cdot 06$ \\
\hline Accessible air voids: \% & $3 \cdot 59$ & $3 \cdot 72$ & $4 \cdot 24$ & $4 \cdot 58$ & $4 \cdot 38$ & $3 \cdot 63$ & $3 \cdot 92$ & $4 \cdot 7$ & $4 \cdot 79$ \\
\hline Sorptivity: $\mathrm{mm} / \mathrm{min}^{1 / 2}$ & 0.0338 & 0.0533 & 0.5320 & 0.5510 & 0.6330 & 0.0422 & 0.0425 & $0 \cdot 5100$ & 0.0457 \\
\hline
\end{tabular}

Table 5. Density, water absorption, porosity and sorptivity coefficient of the hardened concretes

The concrete specimens were kept in their moulds for $24 \mathrm{~h}$. The moulds were covered with wet burlap and plastic to ensure that the temperature and wet conditions would remain stable between $18^{\circ} \mathrm{C}$ and $26^{\circ} \mathrm{C}$ with a high moisture content. After demoulding $(24 \mathrm{~h}$ after casting), the specimens were cured in a humidity-controlled room at $23^{\circ} \mathrm{C}$ and $95 \%$ humidity until the age of testing.

\section{Tests of hardened concrete properties \\ Physical properties}

The density, absorption and voids were measured following ASTM C 642-97 (ASTM, 1997) (standard test method for density, absorption, and voids in hardened concrete) at $28 \mathrm{~d}$. Three cube specimens were used in this test for each type of concrete produced.

\section{Mechanical properties}

The compressive strengths of the concretes were determined using a compression machine with a loading capacity of $3000 \mathrm{kN}$. The compressive strength of the cylindrical specimens was measured at the ages of $7 \mathrm{~d}, 28 \mathrm{~d}$ and $365 \mathrm{~d}$ ( 1 year) following UNE EN 12390-3 (Aenor, 2011). Each presented value is the average of three measurements. The splitting tensile strength and elastic modulus were tested at $28 \mathrm{~d}$, following UNE EN 12390-6 (Aenor, 2010) and UNE 12390-13 (Aenor, 2013) specifications respectively. Three specimens were used for each type of concrete produced.

\section{Durability properties}

\section{CAPILLARY WATER ABSORPTION}

The concrete's capillary water absorption was assessed using $100 \times 100 \times 100 \mathrm{~mm}$ cubic specimens at $28 \mathrm{~d}$ after mixing following the Swiss standard SIA 162/1 (SIA, 1989). For sorptivity determination, the specimens were previously ovendried at $40^{\circ} \mathrm{C}$ until a constant weight was obtained. The bottom face of the specimens was then submerged in water to a depth of $5 \mathrm{~mm}$ (the lateral surfaces were impregnated with impermeable resin). The cumulative water absorbed was recorded at different time intervals up to $120 \mathrm{~min}$ by weighing the specimen after removing surface water using a dampened tissue. The results of capillary water absorption are the average of three measurements.

\section{CHLORIDE ION PENETRABILITY}

The rate of chloride ion ingress into concrete is primarily dependent on the internal pore structure. The pore structure is defined by the type of cement paste, the quality of the ITZ and the porosity of the aggregates. It is considered that concrete should be evaluated for chloride permeability wherever there is a potential risk of chloride-induced corrosion (Joshi and Chan, 2002). 


\section{Offprint provided courtesy of www.icevirtuallibrary.com Author copy for personal use, not for distribution}

The chloride penetrability of concrete was determined in accordance with ASTM C1202 (ASTM, 2012) using a $50 \mathrm{~mm}$ long, $100 \mathrm{~mm}$ diameter concrete section cut from the middle of a $100 \varnothing / 200 \mathrm{~mm}$ concrete cylinder. The three middle sections obtained from one cylinder were tested at different ages. The external $20 \mathrm{~mm}$ sections of the cylinder were rejected. The resistance of concrete to chloride ion penetration is represented by the total charge passed, in coulombs, through a water-saturated concrete section during a test period of $6 \mathrm{~h}$. In this study, the chloride ion penetrability test was carried out on concrete specimens at the ages of $28 \mathrm{~d}, 6$ months and 1 year; each result is the average of three measurements.

\section{Results and discussion}

\section{Physical properties}

\section{Density, water absorption and accessible pore tests}

The obtained results are presented in Table 5. The replacement of natural sand by fine RAs (PCS or MMS) produced a reduction in density and an increase in absorption capacity and accessible air voids of the hardened concrete. Similar results were reported by Khatib (2005) and López et al. (2007). The higher the percentage of RA used, the greater the difference between the values for the RA concrete and conventional concrete. Due to the lower density of the MMS aggregates, concrete mixes produced with those aggregates obtained lower density than those made with PCS aggregates. Nevertheless, the decrease in the density of concrete produced with 50\% MMS aggregates was lower than 5\% when compared with that of conventional concrete.

Figure 2 shows the influence of the use of fine RAs on the absorption capacity and accessible porosity. The influence of fine RAs on these properties was greater than on the density of the recycled concrete because the difference in absorption capacity of RAs and natural aggregates was higher than the difference between their densities. The increase in absorption capacity of concretes made with $35 \%$ and $50 \%$ fine RAs was

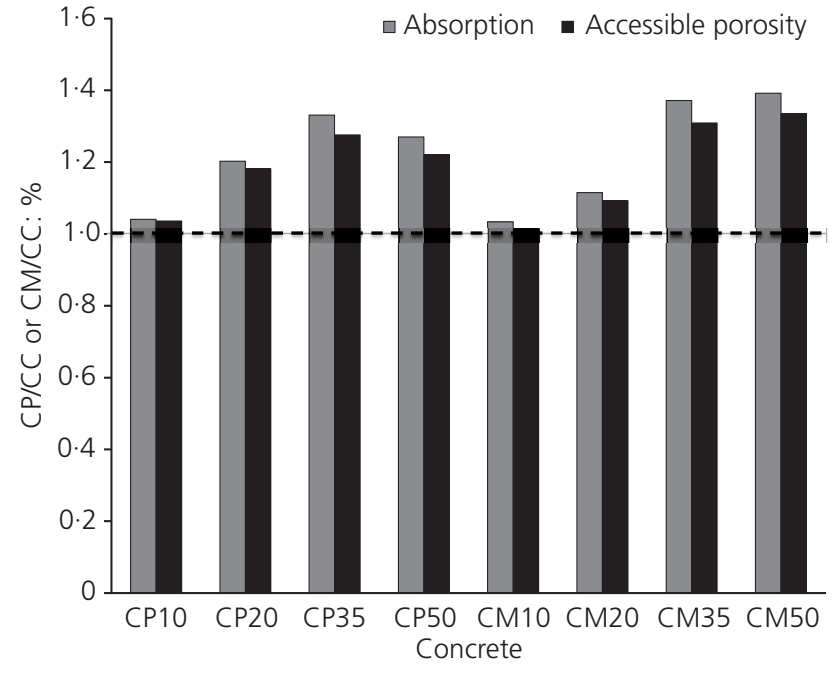

Figure 2. Water absorption and accessible porosity of RA concretes (CP or $\mathrm{CM}$ ) compared with conventional concrete (CC) at $28 \mathrm{~d}$

similar. The absorption capacity of CM50 concretes increased by $40 \%$ with respect to that of conventional concrete after $28 \mathrm{~d}$ of curing.

\section{Mechanical properties}

\section{Compressive strength}

Table 6 shows the compressive strength values obtained by all the concretes studied at $7 \mathrm{~d}, 28 \mathrm{~d}$ and $365 \mathrm{~d}$. At $7 \mathrm{~d}$, the conventional concrete exhibited similar strength to that of the concretes made with PCS aggregates but, after $28 \mathrm{~d}$ of curing, all the concretes made with fine RAs (CP and CM concretes produced with all the percentages of aggregates indicated) showed a higher compressive strength than the conventional concrete. The medium-low $\mathrm{w} / \mathrm{c}$ ratio and adequate bond strength of the fine RAs (PCS and MMS) enabled the RA concretes to show comparable behaviour

\begin{tabular}{lccccc}
\hline & \multicolumn{2}{c}{ Compressive strength: MPa } & $\begin{array}{c}\text { Splitting tensile } \\
\text { strength }\end{array}$ & $\begin{array}{c}\text { Modulus of } \\
\text { elasticity } \\
\text { at 28 d: MPa }\end{array}$ \\
\cline { 2 - 3 } & $7 d$ & $28 d$ & $365 d$ & at 28 d: MPa & 39546 \\
\hline CC & $51 \cdot 0$ & $52 \cdot 5$ & $63 \cdot 2$ & $4 \cdot 51$ & 38776 \\
CP10 & $47 \cdot 7$ & $56 \cdot 2$ & $66 \cdot 2$ & $4 \cdot 57$ & 40410 \\
CP20 & $52 \cdot 7$ & $56 \cdot 9$ & $69 \cdot 5$ & $4 \cdot 63$ & 38750 \\
CP35 & $51 \cdot 5$ & $58 \cdot 3$ & $79 \cdot 3$ & $4 \cdot 84$ & 40942 \\
CP50 & $48 \cdot 7$ & $57 \cdot 2$ & $69 \cdot 0$ & $4 \cdot 90$ & 37346 \\
CM10 & $55 \cdot 9$ & $61 \cdot 1$ & $70 \cdot 8$ & $4 \cdot 30$ & 39311 \\
CM20 & $56 \cdot 2$ & $57 \cdot 8$ & $71 \cdot 9$ & $4 \cdot 15$ & 34126 \\
CM35 & $51 \cdot 2$ & $52 \cdot 0$ & $71 \cdot 4$ & $4 \cdot 40$ & 35298 \\
CM50 & $50 \cdot 3$ & $54 \cdot 5$ & $68 \cdot 0$ & 4.65 &
\end{tabular}

Table 6. Mechanical properties of concretes 
to that of conventional concrete (Neville, 1995). According to some researchers (Higashiyama et al., 2012a, 2012b; López et al., 2007; Pacheco-Torgal and Jalali, 2010; Torkittikul and Chaipanich, 2010) an improved interfacial zone due to the use of rough ceramic, as well as the strength of the sintered ceramic (mullite), contributes to this increase in strength. Taha and Nounu (2008) also reported that aggregate texture plays an important role in the compressive strength of concrete. The presence of water in the PCS and MMS aggregates allowed adequate hydration of the cement through internal curing, improving the cement hydration and consequently the concretes' properties (ACI, 1997; Suzuki et al., 2009). The microstructures of the improved ITZ and the ITZ in lightweight aggregate concrete showed similarities. Moreover, several authors have found higher compressive strength results through the use of lightweight aggregates (Bentz, 2007; Espinoza-Hijazin and Lopez, 2011; Golias et al., 2012) or self-healing effects (Șahmaran et al., 2014) as internal curing agents contribute to better hydration of the cementitious system.

An analysis of the highest compressive strengths obtained indicates that concretes made with $20 \%$ and $35 \%$ of either type of fine RA were adequate for use. The highest compressive strength was obtained in concretes made with $35 \%$ of PCS (fine ceramic) aggregate. The lower strength of the CM concretes is probably due to the more heterogeneous composition of the MMS (mixed) aggregate and the presence of soft material.

Figure 3 shows that the concretes made with more than $20 \%$ of fine RAs achieved a higher increase in compressive strength from $28 \mathrm{~d}$ to $365 \mathrm{~d}$ than conventional concrete. Concretes made with $35 \%$ of PCS and MMS obtained the highest increase over that period, which could be attributed to the pozzolanic effect of the ceramic aggregates (Vegas et al., 2011) (the MMS aggregate also contained $70 \%$ ceramic material). The good results obtained with the MMS aggregates could also be due to the estimation of a lower water absorption rate $(80 \%)$ than the aggregates actually had $(80 \%$ was the absorption capacity of aggregates submerged for $20 \mathrm{~min}$ ).

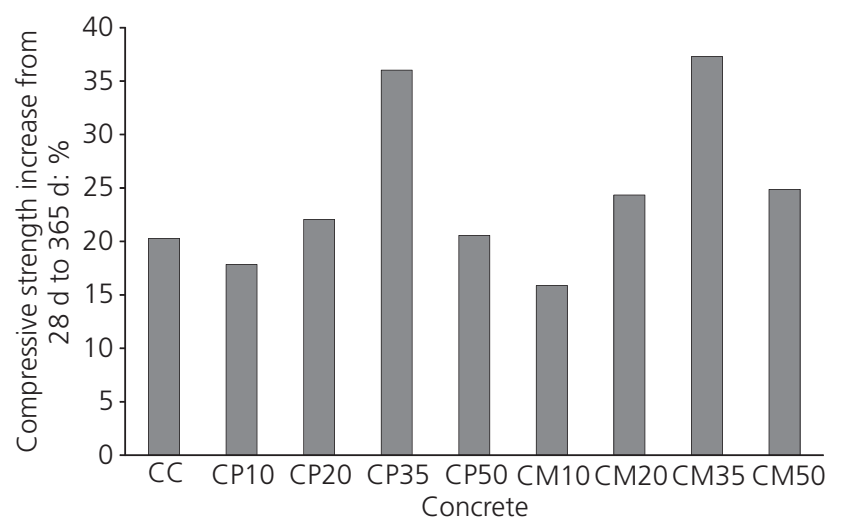

Figure 3. Compressive strength increase from $28 d$ to $365 d$ of curing
Although the compressive strength decreased with an increase in the replacement ratio of recycled brick aggregates in the study of Alves et al. (2014), a higher rate of strength development occurred for mixes incorporating brick aggregates compared with the reference concrete. The same behaviour was reported by Khatib (2005) and was attributed to possible pozzolanic activity of the brick aggregates. Another reason for the higher rate of strength development reported by Cachim (2009) is that the higher water content of the mixes (in order to maintain the same workability) leads to later hydration of the cement (internal curing); this was also described by Pacheco-Torgal and Jalali (2010).

\section{Splitting tensile strength and modulus of elasticity}

All the RA concretes studied achieved similar splitting tensile strengths to that of conventional concrete, as shown in Table 6 . All the concretes made with PCS (fine ceramic) aggregates obtained a higher splitting tensile strength than did the conventional concrete. This is probably due to the rougher surface of this type of RA (López et al., 2007; Mansur et al., 1999) and a higher pozzolanic effect and thus the production of an effective ITZ (Khatib, 2005). Among the RA concretes, those produced with $50 \%$ fine RA showed the highest splitting tensile strength. The fine RAs were used in a dry condition and their absorption capacity facilitated the adequate adherence of the cement to their surface when water was absorbed (Etxeberria et al., 2006).

Figure 4(a) shows the ITZ of concrete made with PCS aggregate; the fine ceramic aggregate marked by the square is detailed in Figure 4(b). The fine ceramic grain had an adequate ITZ due to cement accumulation on the interface. Torkittikul and Chaipanich (2010) also reported that concretes made with $50 \%$ of ceramic waste aggregate had no cracks between the interfaces of the ceramic aggregate particles and the cement paste. This is consistent with the fact that the compressive strength of the specimens containing ceramic waste aggregate was higher than that of the control mix.

The modulus of elasticity of the concrete made with fine RAs was similar to that of the conventional concrete - expected behaviour due to the fact that the modulus of elasticity is determined by the coarse aggregate used in the manufacture of the concrete (Neville, 1995). The concretes produced with $35 \%$ and $50 \%$ MMS aggregates suffered a slight reduction in elastic modulus (see Table 6); this is probably due to lower stiffness of the mortar adhered to the MMS aggregates. Similarly, Evangelista and de Brito (2007) concluded that the elastic modulus values of concretes made with $30 \%$ of fine concrete RAs as a substitute of natural sand were significantly lower than those of conventional concrete.

Figure 5 shows that the concretes made with PCS aggregates achieved the splitting tensile strength values obtained by the conventional concretes. Concretes produced with mixed fine 
Magazine of Concrete Research Volume 67 Issue 12
Effect of fine ceramic recycled aggregate

(RA) and mixed fine RA on hardened

properties of concrete

Etxeberria and Vegas

\section{Offprint provided courtesy of www.icevirtuallibrary.com Author copy for personal use, not for distribution}

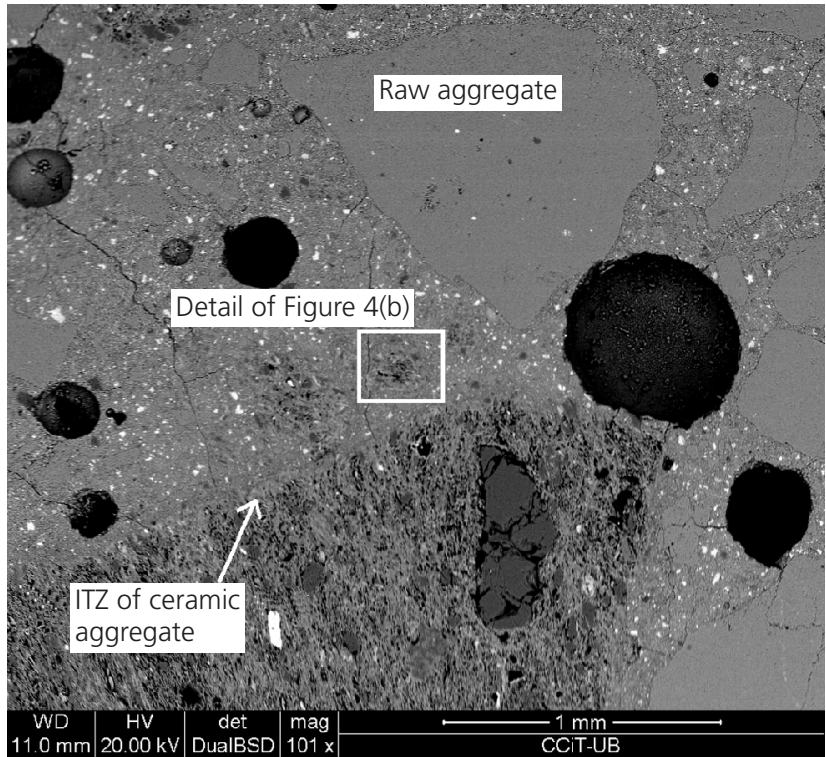

(a)

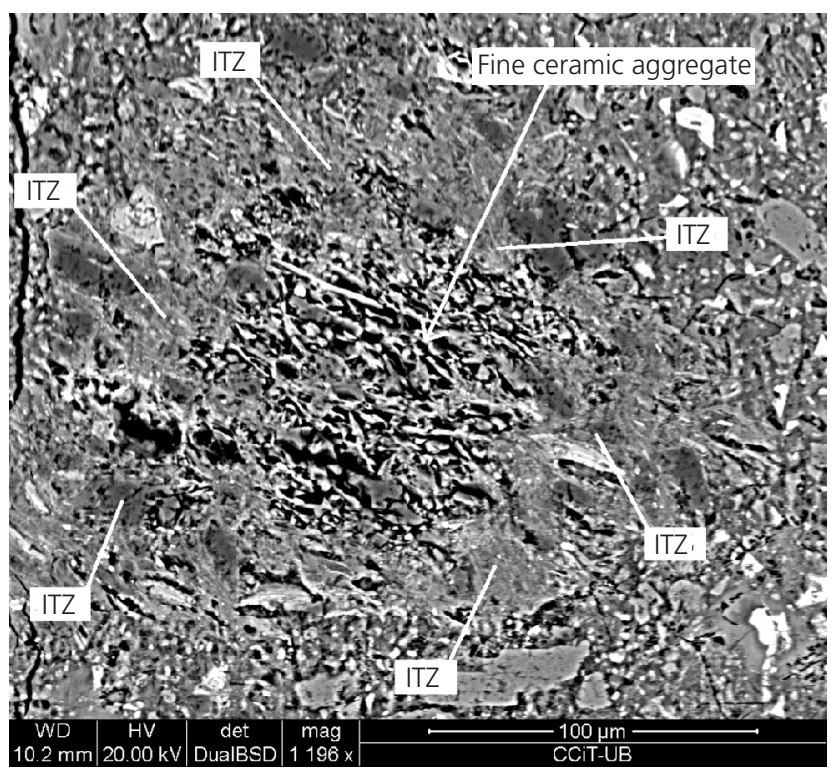

(b)

Figure 4. The ITZ of concrete made with PCS aggregate. (a) Concrete sample. The ITZ of the ceramic aggregate was adequate (a fine ceramic aggregate is marked inside the square, detailed in (b)). (b) The fine ceramic aggregate. The ITZ was much denser than the aggregate. The ITZ of natural aggregates can be the weakest zone in concrete

aggregates (MMS) showed decreases in splitting tensile strength of $5 \%$ and $8 \%$ for $10 \%$ and $20 \%$ replacements respectively, but the $50 \%$ MMS concrete (CM50) achieved a slightly higher splitting tensile strength than the conventional concrete. According to Alves et al. (2014), the use of superplasticiser eliminates the effect of agglutination between the fine RAs, thus improving

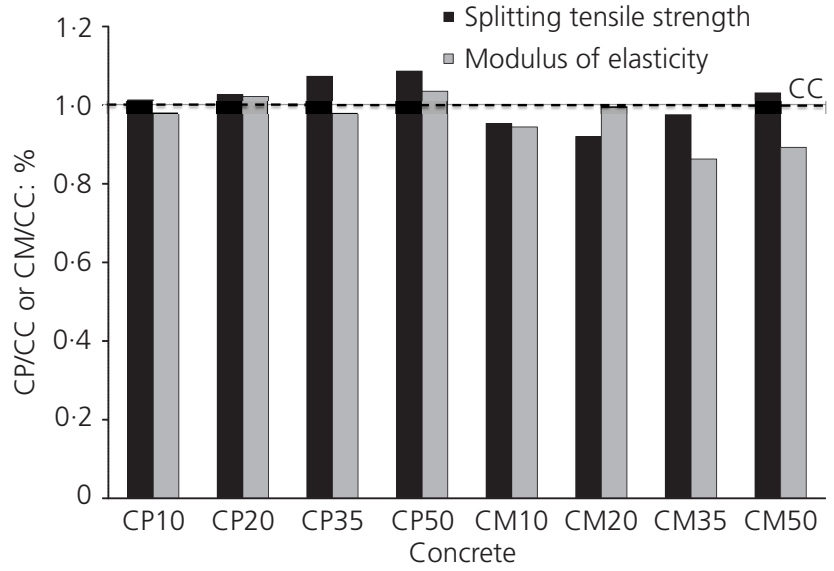

Figure 5. Splitting tensile strength and modulus of elasticity ( $28 d$ of age) of RA concretes compared with conventional concrete

the compressive and splitting strength. Concretes produced with more than $35 \%$ mixed RAs showed a reduction of $13-10 \%$ of the modulus elasticity with respect to that of conventional concrete.

\section{Durability}

Capillary water absorption

The results of assessing the concrete specimens' capillary water absorption over a period of $2 \mathrm{~h}$ are shown in Figure 6: the capillary water absorption of the conventional concrete was lower than that of any of the RA concretes, as also noted by other researchers (Debieb and Kenai, 2008; Evangelista and de Brito, 2010). The concretes made with fine ceramic PCS aggregates (CP concretes) showed a greater capillary absorption capacity than the concretes made with fine mixed RAs (CM concretes). This is most probably due to the grading size distribution of the fine ceramic RA: the PCS had $25 \%$ of aggregates greater than $4 \mathrm{~mm}$ compared with $14 \%$ for MMS and $1 \%$ for natural aggregate). The larger aggregate size produced a connectivity between grains and thus increased the capillary absorption capacity; this

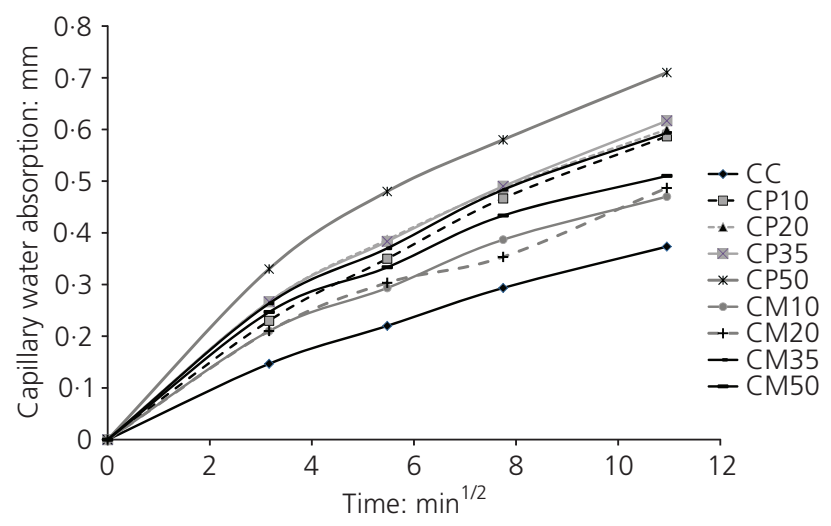

Figure 6. Capillary water absorption 


\section{Offprint provided courtesy of www.icevirtuallibrary.com Author copy for personal use, not for distribution}

has also been reported by other researchers (Levy and Helene, 2004; Wirquin et al., 2000; Zega and Di Maio, 2011). It should also be taken into account that the absorption capacity of RAs was considered to be $80 \%$ at concrete production, but was probably higher, resulting in a lower effective w/c ratio of recycled concrete than was expected and consequently a denser cement paste.

The sorptivity values (Table 5) of all concretes ranged from $0.0338 \mathrm{~mm} / \mathrm{min}^{1 / 2}$ for conventional concrete to $0.0633 \mathrm{~mm} / \mathrm{min}^{1 / 2}$ for CP50 (produced with $50 \%$ fine ceramic aggregate). The sorptivity values obtained in the first $2 \mathrm{~h}$ can be correlated with concrete w/c ratios. According to Neville (1995), values of $0.09 \mathrm{~mm} / \mathrm{min}^{1 / 2}$ and $0.17 \mathrm{~mm} / \mathrm{min}^{1 / 2}$ correspond to concretes with w/c ratios of 0.4 and 0.6 respectively. Gonzalez-Corominas and Etxeberria (2014) found a sorptivity value of $0.016 \mathrm{~mm} / \mathrm{min}^{1 / 2}$ for concrete made with $15 \%$ ceramic fine aggregate in place of natural sand using an effective w/c ratio of 0.0285 ; the concrete made with $15 \%$ of fine aggregates achieved a similar sorptivity to that of conventional concrete. Discontinuity of the pores due to the homogeneous distribution of sand grains through the cement paste had little influence on this property. However, the tests affirmed that the quality of the cement paste and w/c ratio had more influence on sorptivity than the replacement level of the RAs.

\section{Chloride ion penetrability}

The chloride penetration resistance of the concretes was assessed at $28 \mathrm{~d}, 6$ months and 1 year of curing. Figure 7 shows that the resistance to chloride ion penetration at $28 \mathrm{~d}$ for the concretes made with mixed recycled fine aggregates decreased with an increase in RA content. The concretes produced with $35 \%$ and $50 \%$ of ceramic fine RAs had the highest resistance to chloride ion penetration due to the presence of high-density cement paste in the ITZ as shown in Figure 4. The splitting tensile strengths of CP35 and CP50 concretes were also the highest (see Table 6).

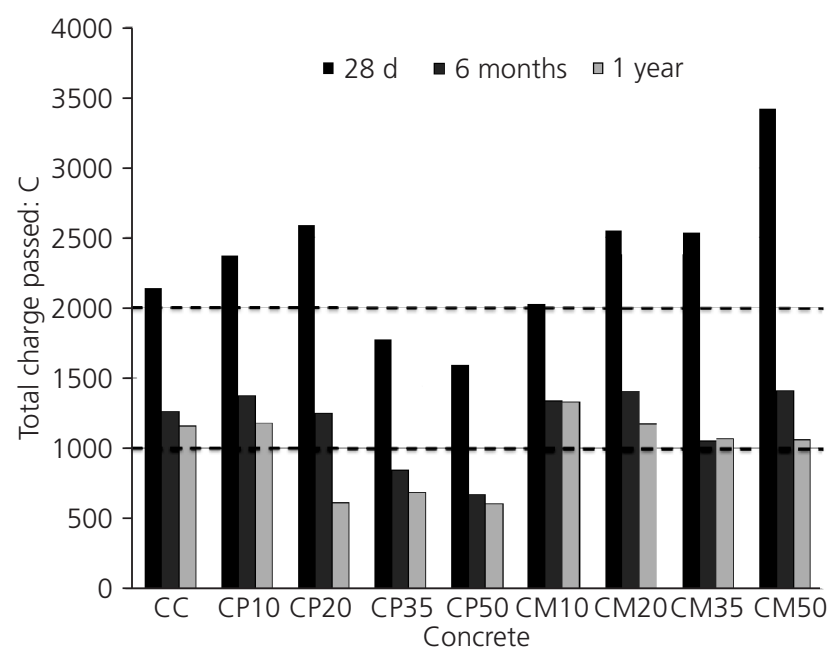

Figure 7. Total charge passed through concretes at $28 d$, 6 months and 1 year age of curing
After 6 months and 1 year of curing, the concretes with ceramic RA showed a lower chloride penetration than that of conventional concrete, although concretes with $20 \%$ of ceramic RAs had a higher resistance to chloride than that of conventional concrete. Pacheco-Torgal and Jalali (2010) and Higashiyama et al. (2012a, $2012 \mathrm{~b}$ ) also concluded that the durability of concretes improved significantly in concretes produced with fine ceramic aggregates. Binici (2007) concluded that the use of fine ceramic aggregate as a substitution of up to $60 \%$ natural sand strongly improved the chloride penetration resistance of the concretes produced. As shown in Figure 7, the concretes can be classified according to ASTM C1202 (ASTM, 2012) corrosion ranges as between very low and low risk of corrosion after 1 year.

Figure 8 shows the increase of chloride resistance in all the concretes from $28 \mathrm{~d}$ to 1 year of age. The conventional concrete achieved an increase of $45 \%$ over this time period. All the concretes produced with more than $20 \%$ of ceramic or mixed RAs achieved a higher increase of resistance compared with the conventional concrete. Concrete CP20, made with $20 \%$ of fine ceramic aggregate, achieved the highest reduction with respect to the electrical charge passed through the concrete. This is probably due to adequate internal curing and some pozzolanic effect (Gonzalez-Corominas and Etxeberria, 2014): highly hydrated cement paste produces a dense mortar, which is quite impermeable. Zhutovsky and Kovler (2012) also obtained an improvement in chloride penetration resistance in concretes produced with low percentages of fine lightweight aggregates as a substitution for natural aggregates. Due to their water absorption capacity, the lightweight aggregates produced internal curing, which improved the cement hydration. That effect did not appear in the capillary water absorption test, as also confirmed in this research work.

\section{Conclusions}

The following conclusions can be made based on the results of this study.

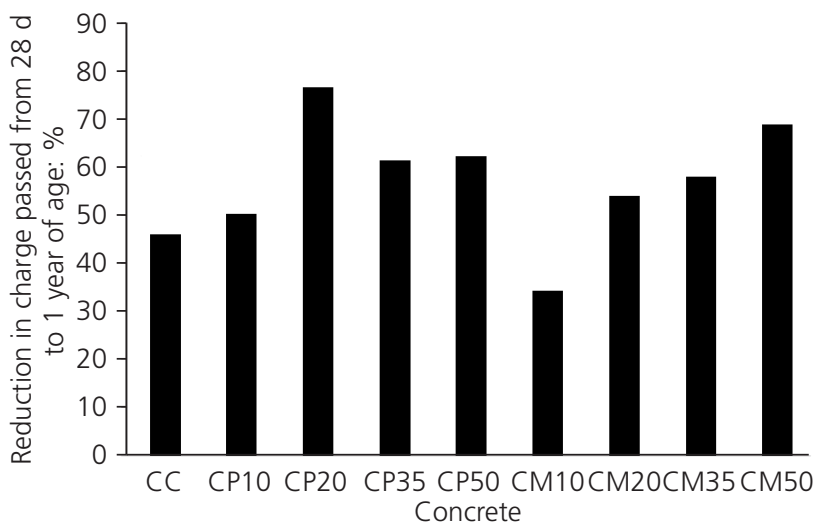

Figure 8. Reduction in charge passed through the concretes at 1 year of age with respect to $28 d$ value 


\section{Offprint provided courtesy of www.icevirtuallibrary.com Author copy for personal use, not for distribution}

- The use of up to $50 \%$ of fine ceramic or mixed recycled aggregates as a substitute for natural sand caused a reduction in concrete density of less than $5 \%$ compared with conventional concrete. However, the absorption increased by more than $40 \%$ in comparison with conventional concrete.

- The early-age compressive strength of concrete made with fine RAs was lower than that of conventional concrete. However, after $28 \mathrm{~d}$ of curing, all the concretes produced using up to $50 \%$ of fine RAs achieved a higher strength than the conventional concrete.

- Due to the ceramic grains in both types of fine RA used in this work, the increase in compressive strength of the RA concrete from $28 \mathrm{~d}$ to $365 \mathrm{~d}$ was higher than that of conventional concrete. The concrete made with $35 \%$ fine ceramic RA or mixed RA as a substitute for natural sand achieved the greatest increase in compressive strength.

- The values of splitting tensile strength and modulus of elasticity of the RA concretes were similar to those of conventional concrete.

- The chloride resistance of concrete made with up to $50 \%$ of ceramic or mixed fine RAs at 1 year was similar or better than that of conventional concrete. The presence of ceramic fine grains caused a reduction of chloride ion penetrability in the concretes.

According to this work, the use of low percentages of ceramic or mixed fine aggregate as a substitution for natural sand could improve the properties of high-strength concretes. Over time, the properties of RA concrete improved more than those of conventional concrete, and consequently similar or better properties were obtained for the RA concrete. As has also been demonstrated by other researchers, the use of low percentages of high absorption capacity aggregates for concrete production allows internal curing of the concrete and mitigates autogenous shrinkage. The use of low percentages of recycled ceramic or mixed fine is thus considered suitable for the production of precast elements and/or high-volume concrete elements.

\section{Acknowledgements}

The authors acknowledge support from Gestora de runes de la Construcció S.A. and Piera Ecocerámica in the supply of the recycled aggregates and rejected bricks used in this study. The first author also wishes to acknowledge the financial support of the Ministry of Economy and Competitiveness of the Government of Spain (MINECO) for providing funds for the INNPACT project (IPT-2012-1093-310000) and the European Regional Development Fund (FEDER).

\section{REFERENCES}

ACI (American Concrete Institute) (1997) State-of-the-Art Report on High-Strength Concrete. ACI, Farmington Hills, MI, USA, Report ACI 363R.

Aenor (2006) UNE EN 12350-2:2006. Testing fresh concrete. Part 2: Slump test. Aenor, Madrid, Spain.
Aenor (2010) UNE EN 12390-6:2010. Testing hardened concrete - Part 6: Tensile splitting strength of test specimens. Aenor, Madrid, Spain.

Aenor (2011) UNE EN 12390-2:2009/AC:2011. Testing hardened concrete - Part 3: Compressive strength of test specimens. Aenor, Madrid, Spain.

Aenor (2013) UNE EN 12390-13:2014. Testing hardened concrete - Part 13: Determination of secant modulus of elasticity in compression. Aenor, Madrid, Spain.

Alves AV, Vieira TF, de Brito J and Correia JR (2014) Mechanical properties of structural concrete with fine recycled ceramic aggregates. Construction and Building Materials 64(14): 103-113.

ASTM (1997) C 642-97. Standard test method for density, absorption, and voids in hardened concrete. ASTM International, West Conshohocken, PA, USA.

ASTM (2012) C1202-12. Standard test method for electrical indication of concrete's ability to resist chloride ion penetration. ASTM International, West Conshohocken, PA, USA.

Bentz DP (2007) Internal curing of high-performance blended cement mortars. ACI Materials Journal 104(4): 408-414.

Binici H (2007) Effect of crushed ceramic and basaltic pumice as fine aggregates on concrete mortars properties. Construction and Building Materials 21(6): 1191-1197.

BSI (1996) EN 993-2:1996. Tests for geometrical properties of aggregates. Determination of particle size distribution. Test sieves, nominal size of apertures. BSI, London, UK.

Cachim PB (2009) Mechanical properties of brick aggregate concrete. Construction and Building Materials 23(3): 12921297.

Correia JR, de Brito J and Pereira AS (2006) Effects on concrete durability of using recycled ceramic aggregates. Materials and Structures 39(2): 169-177.

Debieb F and Kenai S (2008) The use of coarse and fine crushed bricks as aggregate in concrete. Construction and Building Materials 22(5): 886-893.

de Brito J, Pereira AS and Correia JR (2005) Mechanical behavior of non-structural concrete made with recycled ceramic aggregates. Cement \& Concrete Composites 27(4): 429-433.

EHE (La Instrucción Española del Hormigón Estructural) (2008) Instrucción de Hormigón Estructural. Comisión Permanente del Hormigón, Ministerio de Fomento, España. Anejo 15, Recomendaciones para la utilización de hormigones reciclados. See www.fomento.es (accessed 16/11/2014).

Espinoza-Hijazin G and Lopez M (2011) Extending internal curing to concrete mixtures with $\mathrm{w} / \mathrm{c}$ higher than $0 \cdot 42$. Construction and Building Materials 25(3): 1236-1242.

Etxeberria M, Vázquez E and Marí AR (2006) Microstructure analysis of hardened recycled aggregate concrete. Magazine of Concrete Research 58(10): 683-690.

Etxeberria M, Vázquez E, Marí A and Barra M (2007) Influence of amount of recycled coarse aggregates and production 
process on properties of recycled aggregate concrete. Cement and Concrete Research 37(5): 735-742.

European Commission (1999) Construction and Demolition Waste Management Practices, and Their Economic Impacts. Report to DGXI EC. See http://ec.europa.eu/ environment/waste/studies/cdw/cdw_report.htm (accessed 15/11/2014).

Evangelista L and de Brito J (2007) Mechanical behaviour of concrete made with fine recycled concrete aggregates. Cement \& Concrete Composites 29(5): 397-401.

Evangelista L and de Brito J (2010) Durability performance of concrete made with fine recycled concrete aggregates. Cement \& Concrete Composites 32(1): 9-14.

Golias M, Castro J and Weiss J (2012) The influence of the initial moisture content of lightweight aggregate on internal curing. Construction and Building Materials 35: 52-62.

Gomes M and de Brito J (2009) Structural concrete with incorporation of coarse recycled concrete and ceramic aggregates: durability performance. Materials and Structures 42(5): 663-675.

Gonzalez-Corominas A and Etxeberria M (2014) Properties of high performance concrete made with recycled fine ceramic and coarse mixed aggregates. Construction and Building Materials 68(15): 618-626.

Halickaa A, Ogrodnik P and Zegardloc B (2013) Using ceramic sanitary ware waste as concrete aggregate. Construction and Building Materials 48: 295-305.

Hansen TC (1986) Recycled aggregate and recycled aggregate concrete, second state-of-the-art report developments 19451985. Materials and Structures 19(3): 201-246.

Hansen TC (1992) RILEM: Recycling of Demolished Concrete and Masonry. Report of Technical Comité 37-DRC: Demolition and Reuse of Concrete. Chapman \& Hall, London, UK.

Higashiyama H, Yagishita F, Sano M and Takahashi O (2012a) Compressive strength and resistance to chloride penetration of mortars using ceramic waste as fine aggregate. Construction and Building Materials 26(1): 96-101.

Higashiyama H, Sappakittipakorn M, Sano M and Yagishita F (2012b) Chloride ion penetration into mortar containing ceramic waste aggregate. Construction and Building Materials 33: 48-54.

Jimenez JR, Agrela F, Ayuso J and Lopez MA (2010) Comparative study of recycled aggregates from concrete and mixed debris as material for unbound road sub-base. Materiales de Construcción 61(302): 289-302.

Joshi P and Chan C (2002) Rapid Chloride Permeability Testing. Harley-Wood LLC, Corbin, KY, USA, C02L037.

Khatib JM (2005) Properties of concrete incorporating fine recycled aggregate. Cement and Concrete Research 35(4): 763-769.

Levy SM and Helene P (2004) Durability of recycled aggregates concrete: a safe way to sustainable development. Cement and Concrete Research 34(11): 1975-1980.

Limbachiya MC, Leelawat T and Dhir RK (2000) Use of recycled concrete aggregate in high-strength concrete. Materials and Structures. 33(9): 574-580.

López V, Llamas B, Juan A, Morán JM and Guerra I (2007) Eco-efficient concretes: impact of the use of white ceramic powder on the mechanical properties of concrete. Biosystems Engineering 96(4): 559-564.

Mansur MA, Wee TH and Cheran LS (1999) Crushed bricks as coarse aggregate for concrete. ACI Materials Journal 96(4): 478-484.

Medina C, Sánchez De Rojas MI and Frías M (2012) Reuse of sanitary ceramic wastes as coarse aggregate in eco-efficient concretes. Cement and Concrete Composites 34(1): 48-54.

Medina C, Sánchez De Rojas MI and Frías M (2013) Properties of recycled ceramic aggregate concretes: water resistance. Cement \& Concrete Composites 40: 21-29.

MMAMRM (Ministerio de Medio Ambiente, y Medio Rural y Marino) (2009) Plan Nacional Integrado de Residuos para el Periodo 2008-2015. MMAMRM, Madrid, Spain, Boletín Oficial del Estado D. L.: M-1/1958, BOE no. 49 ISSN 0212033X (in Spanish).

Neville AM (1995) Properties of Concrete, 4th edn. PearsonLongman Education, London, UK.

Pacheco-Torgal F and Jalali S (2010) Reusing ceramic wastes in concrete. Construction and Building Materials 24(5): 832-838.

Poon CS, Shui ZH and Lam L (2004) Influence of moisture states of natural and recycled aggregates on the slump and compressive strength of hardened concrete. Cement and Concrete Research 34(1): 31-36.

Sague-Crentsil KK, Brown T and Taylor AH (2001) Performance of concrete made with commercially produced coarse recycled concrete aggregate. Cement and Concrete Research 31(5): 707-712.

Sahmaran M, Yildirim G, Ozbay E, Ahmed K and Lachemi M (2014) Self-healing ability of cementitious composites: effect of addition of pre-soaked expanded perlite. Magazine of Concrete Research 66(8): 409-419.

Senthamarai RM and Devadas Manoharan P (2005) Concrete with ceramic waste aggregate. Cement \& Concrete Composites 27(9-10): 910-913.

Senthamarai RM, Manoharan PD and Gobinath D (2011) Concrete made from ceramic industry waste: durability properties. Construction and Building Materials 25(5): 2413-2419.

SIA (1989) 162/1. Concrete structures - materials testing. Swiss Standards Association, Winterthur, Switzerland.

Silva RV, de Brito J and Dhir RK (2014) Properties and composition of recycled aggregates from construction and demolition waste suitable for concrete production. Construction and Building Materials 65(29): 201-217.

Suzuki M, Seddik Meddah M and Sato R (2009) Use of porous ceramic waste aggregates for internal curing of highperformance concrete. Cement and Concrete Research 39(5): 373-381.

Taha B and Nounu G (2008) Properties of concrete contains 
mixed colour waste recycled glass as sand and cement replacement. Construction and Building Materials 22(5): 713-720.

Tavakoli M and Soroushian P (1996) Strengths of recycled aggregate concrete made using field-demolished concrete as aggregate. ACI Materials Journal 93(2): 182-190.

Torkittikul P and Chaipanich A (2010) Utilization of ceramic waste as fine aggregate within Portland cement and fly ash concretes. Cement \& Concrete Composites 32(6): 440-449.

Vegas I, Ibañez JA, Lisbona A, Sáez De Cortazar A and Frías M (2011) Pre-normative research on the use of mixed recycled aggregates in unbound road sections. Construction and Building Materials 25(5): 2674-2682.
Vejmelková E, Keppert M, Rovnaníková P et al. (2012) Properties of high performance concrete containing fine-ground ceramics as supplementary cementitious material. Cement \& Concrete Composites 34(1): 55-61.

Wirquin E, Zaharieva R and Buyle-Bodin F (2000) Use of water absorption by concrete as a criterion of the durability of concrete - application to recycled aggregate concrete. Materials and Structures 33(6): 403-408.

Zega CJ and Di Maio AA (2011) Use of recycled fine aggregate in concretes with durable requirements. Waste Management 31(11): 2336-2340.

Zhutovsky S and Kovler K (2012) Effect of internal curing on durability-related properties of high performance concrete. Cement and Concrete Research 42(1): 20-26.

\section{WHAT DO YOU THINK?}

To discuss this paper, please submit up to 500 words to the editor at journals@ice.org.uk. Your contribution will be forwarded to the author(s) for a reply and, if considered appropriate by the editorial panel, will be published as a discussion in a future issue of the journal. 